Article

\title{
Embryology in Helosis cayennensis (Balanophoraceae): Structure of Female Flowers, Fruit, Endosperm and Embryo
}

\author{
Ana Maria Gonzalez ${ }^{1, *(0)}$, Héctor A. Sato ${ }^{2}$ and Brigitte Marazzi ${ }^{3}$ \\ 1 Facultad de Ciencias Agrarias, Instituto de Botánica del Nordeste (UNNE-CONICET), Sargento Cabral 2131, \\ CP 3400 Corrientes, Argentina \\ 2 Facultad de Ciencias Agrarias (UNJu), Cátedra de Botánica General-Herbario JUA, Alberdi 47, \\ CP 4600 Jujuy, Argentina; hector.a.sato@gmail.com \\ 3 Natural History Museum of Canton Ticino, Viale C. Cattaneo 4, 6900 Lugano, Switzerland; \\ marazzibrigitte@gmail.com \\ * Correspondence: anitama39@gmail.com
}

Received: 30 January 2019; Accepted: 19 March 2019; Published: 22 March 2019

\begin{abstract}
Helosis cayennensis (Balanophoraceae s.str.) is a holoparasite characterised by aberrant vegetative bodies and tiny, reduced unisexual flowers. Here, we analysed the development of female flowers to elucidate their morpho-anatomy and the historical controversy on embryo sac formation. We also studied the developmental origin of inflorescences and the ontogeny of fruits, embryo and endosperm and discussed in a phylogenetic framework. Inflorescences were analysed by optical, fluorescence and scanning electron microscopy. Inflorescences of $H$. cayennensis arise endogenously. Female flowers lack perianth organs, thus only consist of the ovary, two styles and stigmata. Ovules are undifferentiated; two megaspore mother cells develop inside a nucellar complex. The female gametophyte, named Helosis-type, is a bisporic four-celled embryo sac, provided with a typical egg apparatus and a uni-nucleated central cell. Fertilization was not observed, yet a few-celled embryo and cellular endosperm developed. In sum, results confirm that, among Santalales holoparasites, Helosis is intermediate in the reduction series of its floral organs. Although perianth absence best supports the Balanophoraceae s.str. clade, our literature survey on female flower developmental data across Balanophoraceae s.l. highlights the many gaps that need to be filled to really understand these features in the light of new phylogenetic relationships.
\end{abstract}

Keywords: embryo; endosperm; four-celled embryo sac; holoparasites

\section{Introduction}

Balanophoraceae is a relatively small family of 17 genera of root holoparasitic geophytes characterised by an aberrant vegetative and subterranean body, without leaves, stems or roots, called tuber, which may have rhizome-like ramifications [1-5]. These parasitic plants are attached to the root of shrub and tree host species from dark, tropical forests. Inflorescences are the only aerial part of the plant and several of them may appear along rhizomes, making it difficult or impossible to delimit an individual. A peculiarity of the inflorescences is their endogenous origin (in relation to their own tissues), a unique feature in angiosperms [4]. Their flowers are tiny and a wide range of extreme reductions can be observed among genera, especially in female flowers $[1,4]$ and similarly in their seeds, with embryos formed by few cells $[2,4]$.

Despite these shared features, recent phylogenetic analyses of Santalales [5] suggested that Balanophoraceae is paraphyletic and divided into two well-supported, unrelated clades: one consisting of the genera Dactylantus, Hachettea and Mystropetalonun, forming the new family Mystropetalaceae 
(Clade B), the other including Helosis and the remaining genera (Balanophora, Corynaea, Ditepalanthus, Langsdorffia, Lathrophytum, Lophophytum, Ombrophytum, Rhopalocnemis, Scybalium, Sarcophyte and Thonningia), forming the Balanophoraceae s.str. (Clade A). According to these analyses, no morphological synapomorphies appear to exist to distinguish the two clades but this is probably also due to the lack of knowledge on many aspects of these genera. For instance, with the exception of Balanophora and Dactylanthus, the mode of germination and establishment of the host/host relationship are unknown $[2,4,6]$ and cultivation of these holoparasites is still not possible, despite years of hard work $[7,8]$.

Helosis is perhaps one of the relatively less poorly-known genera. It includes three species, the recently discovered $H$. antillensis and $H$. cayennensis (with its two varieties, var. cayennensis and var. mexicana) and H. ruficeps [1,9-11]. The present study focuses on H. cayennensis, as part of a broader project lead by the first author on the embryology of traditionally circumscribed Balanophoraceae (hereafter referred to as Balanophoraceae s.1.) [12-16]. The species was found in 2006 ([17] fontana), growing in a single spot of about $15 \mathrm{~m}^{2}$ in a mesophyll forest of Argentina, where the only evidence of its presence was the appearance of numerous inflorescences at various developmental stages, from barely visible buds hidden in the forest mulch to open mature inflorescences. This finding allowed the beginning of a series of detailed studies on its reproductive anatomy, including the present one.

The highly modified underground vegetative body of H. cayennensis is composed of tubers and rhizome-likes branches lacking buds or leaves $[2,3,18]$. In this monoecious species, $5-10 \mathrm{~cm}$ long spadix-like inflorescences emerge in a short period of time, are covered with peltate hexagonal scales when young and unisexual flowers are embedded in a dense layer of filariae $[2,4,12,19]$. Male and female flowers are clustered, located around each scale of the inflorescence, which acts as a hermaphrodite blossom [1,12]. Gonzalez et al. [12] described the development and structure of the staminate flowers, including pollen formation and the anatomical structure of the inflorescence, whereas female flowers remained unstudied.

Taxonomic studies describe female flowers of Helosis with a concrescence between ovary and calyx and mentioned two alternative perianth forms: an entire ring or bifid papillose projections [1,20-24]. Cardoso and Braga [9] considered the projections at the ovary apex as pieces of perianth and they use this feature in their key of Helosis species. However, no ontogenetic studies exist that demonstrate the origin of these projections or that analysed the origin of the filariae covering the inflorescences and their relation to flowers.

Besides the morphological descriptions in taxonomic studies $[1,25,26]$, the only information about embryo sac and embryo development in H. cayennensis is found in Chodat and Bernard [23] (as H. guyanensis, a synonym). These authors described the presence of two archesporial cells in a nucellus. During the development of the embryo sac each archesporial cell forms two nuclei, one inferior (denominated antipodal) degenerates and the so-called superior polar nucleus divides twice creating the embryo tetranuclear sac, with one egg cell, a pair of synergids and a central cell. They also described the rapid formation of endosperm and a rudimentary embryo but admit that they were unable to see the fertilization itself. In contrast, Fagerlind [19] reported two megaspore mother cells that undergo meiosis and form a bisporic embryo sac, 8-nucleate and Allium-type. He also mentioned that cellular endosperm and a few-celled embryo are produced upon fertilization. Since these two contradictory results, there have been no new studies to re-examine the embryology in this species. This is probably because of the difficulty to collect material, given that it is impossible to detect individuals in the absence of an aerial vegetative body.

In order to fill gaps in our knowledge of the embryological systems of this root holoparasite and in light of such differences in the descriptions, the purpose of this study aimed at investigating the ontogeny and structure of the inflorescence, female flower, embryo sac, endosperm, embryo and fruit formation of Helosis cayennensis var. cayennensis. Results were compared with those found in the literature on other holoparasitic species of Balanophoraceae s.l. and discussed in the context of the new phylogeny [5] that separates the family in two unrelated clades. 


\section{Results}

\subsection{Reproductive Phenology}

The inflorescence of Helosis cayennensis is spadix-like but lacking the spathe typical of a true spadix. The inflorescence has a differentiated axis on a fragile peduncle that raises the oval apical portion with deciduous scales and unisexual flowers embedded in a dense stratum of trichomes called filariae. The male and female flowers are separate but are borne in the same inflorescence.

The flowering and fruiting period takes place within one month, which occurred in December at the Argentine site. The phases of flowering and fruiting are superimposed on the different inflorescences produced by the same runner. The developmental changes in the inflorescence and flowers were divided in four stages (Figure 1).

- Stage I: In the early stages, the inflorescence is underground and develops endogenously from the runners. The axis of inflorescence is covered by a volva that breaks when emerging at ground level (Figure 1a-d). Young inflorescences are covered with tightly arranged scales; peltate, capitate and hexagonal in front view (Figure 1d).

- $\quad$ Stage II, female phase. All flowers are still covered by scales (Figure 1e-f). Female flowers are the first to develop and open. Anthesis progressed acropetally and the stigmas are exposed on the layer of pink filariae (Figure 1f).

- $\quad$ Stage III, male phase: When the scales become black and fall off, the male phase begins. The filariae turn light brown, the male flowers expose the anthers above the layer of filariae and pollen grains are released (Figure 1g). By the time when the male flowers are in full anthesis, the styles in the female flowers have mostly fallen.

- $\quad$ Stage IV, fruiting phase: Inflorescences turn brown to black and the peduncle bends (Figure 1h).
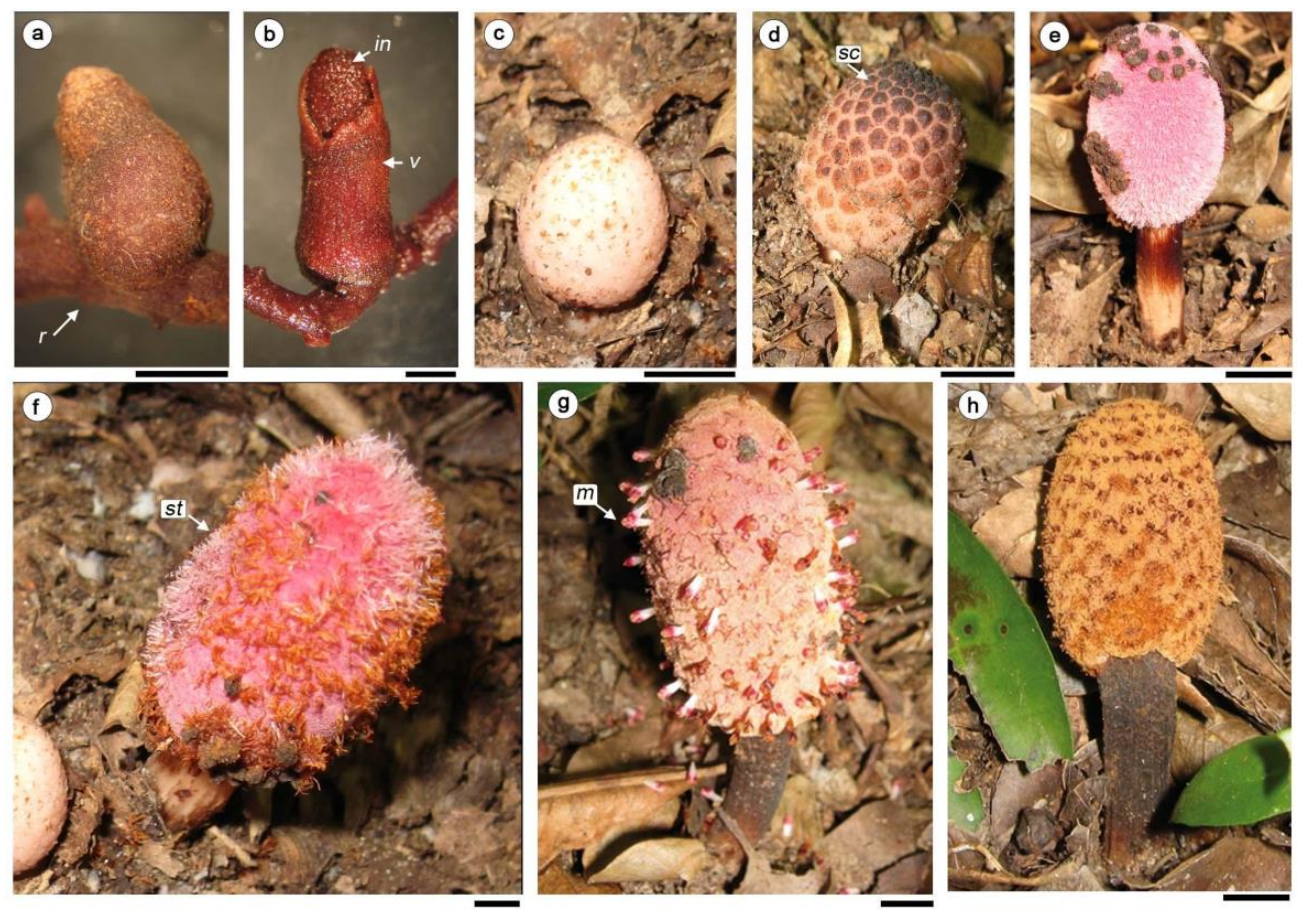

Figure 1. Inflorescence development of H. cayennensis, $(\mathbf{a}, \mathbf{b})$ material in FAA, $(\mathbf{f}-\mathbf{h})$ in the field. $(\mathbf{a}, \mathbf{b}) \mathrm{D}$ stage I. (a) Inflorescence covered by volva. (b) Volva rupture. (c,d) Stage II, flowers covered by scales. (e,f). Stage II, female phase, some scales remain at apex in photo (e). (f) Stage II, stigmata are exposed over the filariae. (g) Stage III: male phase: male flower exposed. (h) Stage IV, fruiting phase. Abbreviations: m: male flowers; in: inflorescence, r: runner; sc: scale; st: stigmata; v: volva. Scale bar= (a,b) $0.2 \mathrm{~mm},(\mathbf{c}-\mathbf{h}) 1 \mathrm{~cm}$. 


\subsection{Floral Morphology and Anatomy}

The female flowers are in compact groups of 30 to 38 around the base of one scale, the male ones surround them in an outer ring. The average flower density is $74 / \mathrm{cm}^{2}$ and the female:male ratio, that is, the floral sex ratio, is 12.6:1. Each female flower is naked, lacking any kind of perianth; it has a gynoecium consisting of a superior ovary and two styles with small capitated stigmata, which are the ones that emerge from the dense layer of filariae (Figure 2a-c).
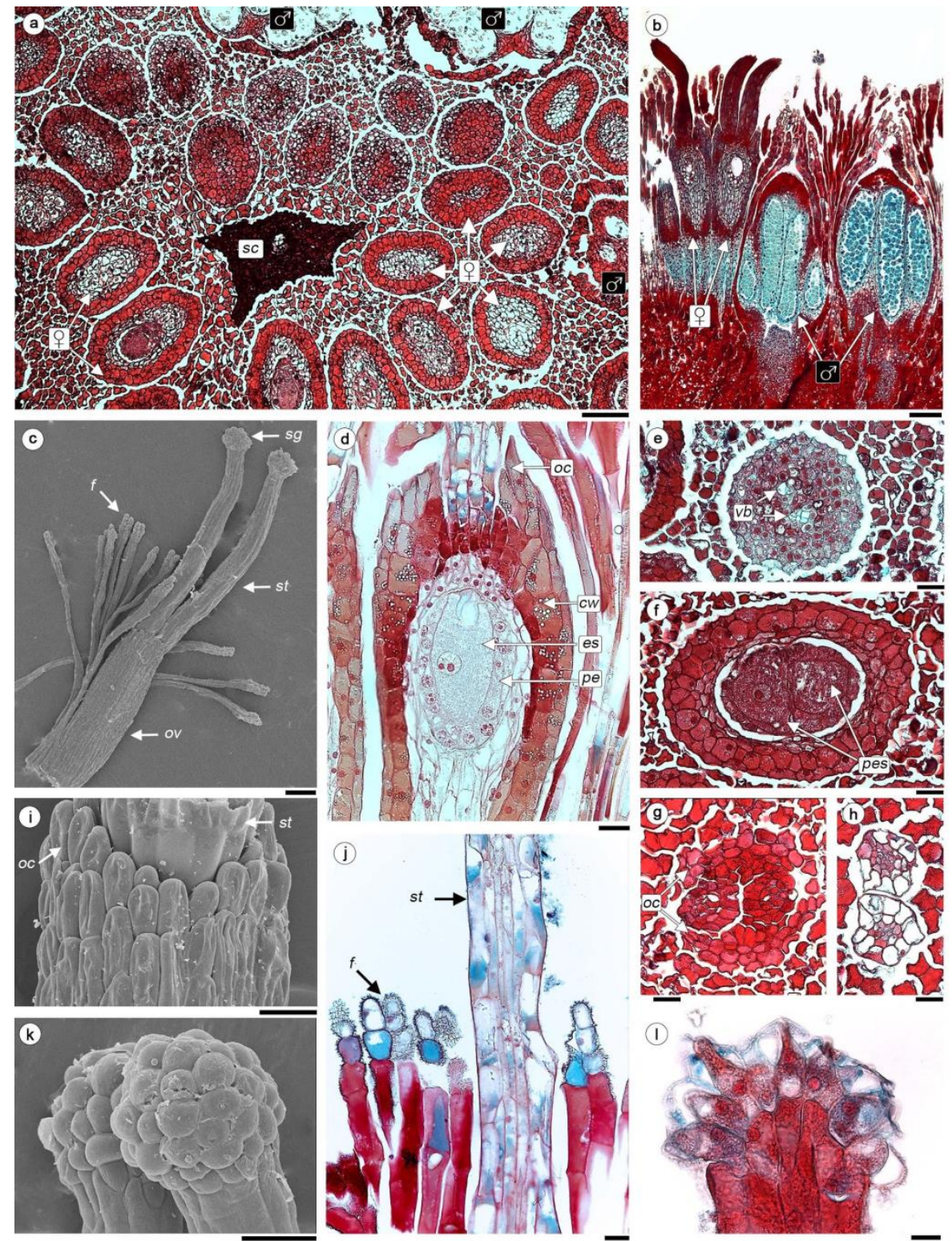

Figure 2. Anatomy of flowers of H. cayennensis (LM). (a) Paradermal section of inflorescence showing female and male flowers disposition around scale base, all the spaces between flowers are occupied by filariae. (b) Longitudinal sections (LS) of inflorescence in the area corresponding to a group of female and male flowers. (c) Female flower at embryo sac stage with same filariae attached. (d) LS of ovary with mature 4-celled embryo sac and pseudo-endothelium. (e-h) Serial TS of female flowers, (e) Pedicel of flower with vascular bundles, (f) ovary with 2 embryo sacs, (g) base of styles and ovary crest (h) styles. (i) Crest at apex of ovary. (j) LS with part of style and filariae. (k) Stigmata. (1) LS of stigmata. Abbreviations: + : female flowers; $\sigma^{\top}$ : male flowers; vb: vascular bundles; cw: carpellar wall; es: embryo sac; f: filariae; oc: ovary crest; ov: ovary; pes: pair of embryo sacs; pe: pseudo-endothelium; sc: scale; sg: stigmata; st: style. Scale bar $=(\mathbf{a}-\mathbf{c}) 0.2 \mathrm{~mm},(\mathbf{c}-\mathbf{i}) 50 \mu \mathrm{m},(\mathbf{j}-\mathbf{l}) 20 \mu \mathrm{m}$. 
The gynoecium reaches a length of 2.24-2.54 mm, of which $1.20-1.26 \mathrm{~mm}$ corresponds to the styles (Figure 2c). A short pedicel supports the ovary (Figure 2b), a vascular bundle that derives directly from the inflorescence axis penetrates the pedicel and reaches the base of the ovary, without entering or branching in it (Figure 2e-f). The absence of any cells with tannin in the pedicel allows its differentiation from the ovary (Figure $2 b$ ). The ovary wall consists of 3-4 layers of tanniferous cells, without vascular bundles (Figure $2 \mathrm{~d}, \mathrm{f}$ ). The entire ovary cavity is occupied by a mass of parenchymatous tissue that is completely fused to the ovary wall, so there is no locule and there is no differentiation of the ovules (Figure 2d). Inside this tissue one (Figure 2d), less frequently two (Figure 2f) embryo sac (ES) develops. A pseudo-endothelium surrounding the ES, their cells contain dense cytoplasm and a large, central nucleus (Figure 2d). The apical portion of the mature ovary has an ovarian crest, it is a ring-shaped excrescence whose cells have a papillose surface (Figure 2d,g,i).

Unlike the ovary, the epidermis in the styles is well defined, consisting of large, vacuolated cells lacking in tannin and covered by a smooth cuticle. The interior region of the styles has 8-12 thin cells in transection and elongated in longitudinal sections (Figure $2 \mathrm{~g}, \mathrm{~h}, \mathrm{j}$ ). The styles do not have any vascularization. The epidermal cells of the stigmata are globose (Figure $2 k, 1)$, the cuticle is much distended, because a dense secretion accumulates between the membrane and cuticle, in LS there is a bottle-shaped lumen, conspicuous nucleus and vacuolated cytoplasm.

Filariae are multicellular trichomes 1.8-2.1 mm long, formed by 3-4 rows of cells; a conspicuous and reticulated cuticle (Figure 2c,j) covers the apical ones. Male flower consists of a 3-lobed tubular perianth and a synandrium composed by three stamens (Figure $2 b$ ).

\subsection{Inflorescence and Female Flower Ontogeny}

In stage I, the young inflorescence, less than $5 \mathrm{~mm}$ in height, is still covered by a volva, formed by a few layers of cells originating from runner tissues (Figure 1a,b and Figure 3a). The development of the inflorescence begins with the formation of scales, which are arranged helically on the axis (Figures $1 \mathrm{~d}$ and $3 \mathrm{a}, \mathrm{b}$ ).

The scales consist of tanniferous parenchyma, lacking a differentiated epidermis and have a central vascular bundle that derives from the axis of the inflorescence (Figure 3b). The tissue located between the scales is formed by 2-4 strata of compact meristematic cells; there is no clear differentiation into layers (Figure $3 b, c)$. Unlike the scales or the axis of the inflorescence, the meristematic cells lack tannic substances or starch grains in the cytoplasm (Figure 3c).

With the growth of the inflorescence axis, the number of strata in the meristematic zones increases and produce floral primordia (Figure $3 \mathrm{~d}$,e). On the rest of the meristematic surface, each cell divides periclinally many times to form compactly arranged filariae (Figure $3 d-f$ ).

The apex of the female flower bud is slightly dome-shaped to flattened (Figure 3d,e). A pair of protrusions develops from the outer edges, which will grow and form two styles and stigmata, which are embedded in the filariae layer at this stage (Figure 3f). The male flower primordium is recognized and distinguished from the female flowers by developing deeper down in the axis of the inflorescence (Figure 3g,h). Within the female floral bud, the apical residue forms a hemispherical structure that grows and occupies the entire ovarian cavity (Figure 3h). In this mass of parenchymatous tissue the placenta and ovules are not differentiated and following Holzapfel ( 7 , see discussion) this structure is called "nucellar complex" (NC), where the embryo sacs (ES) develop in it. 

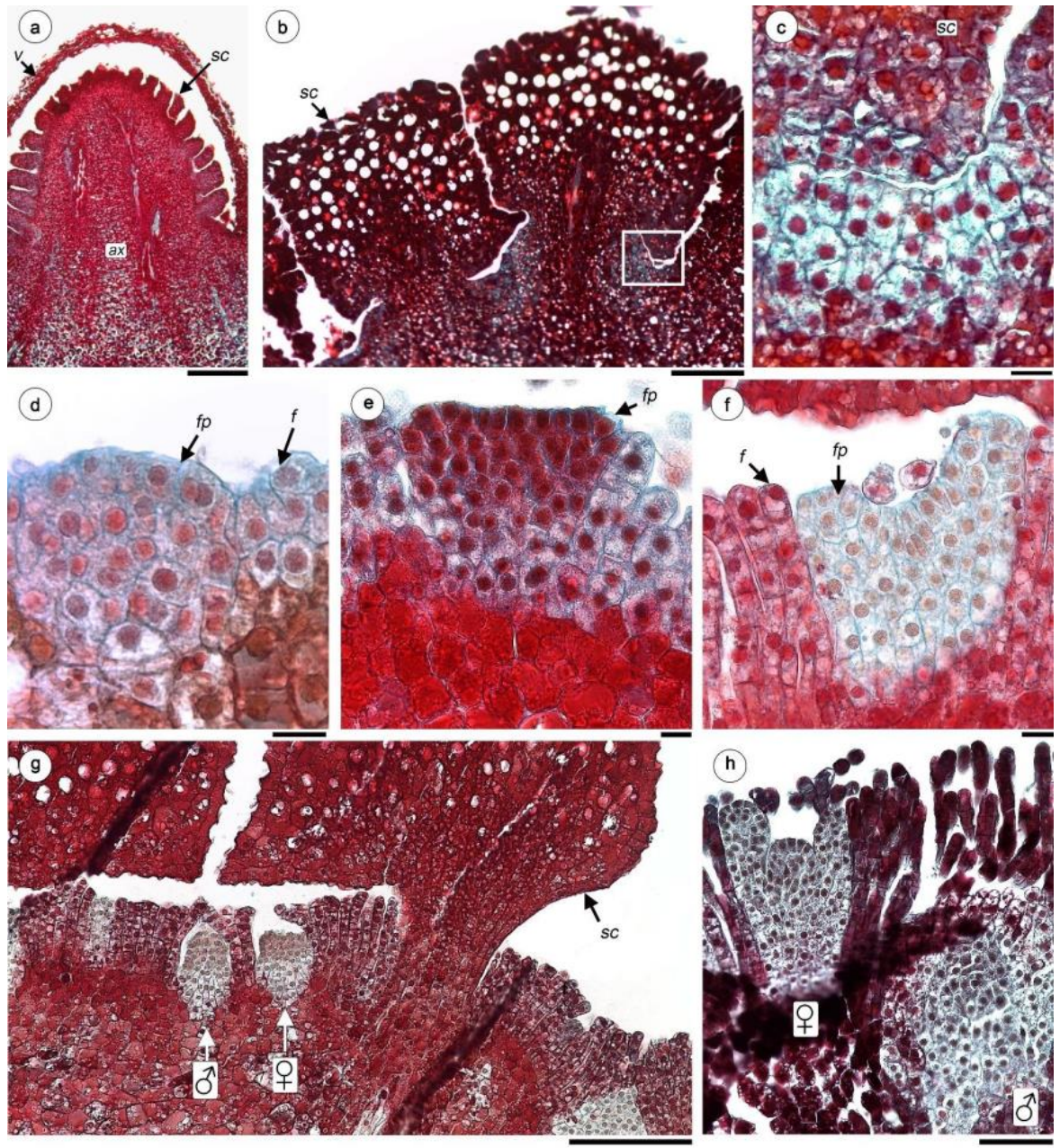

Figure 3. Female flower development of H. cayennensis (LM). (a) Inflorescence primordium still covered by volva. (b) Longitudinal sections of scales-note the meristematic tissue between them (box). (c) Detail of meristematic tissue [corresponds to box in (b)]. (d) Floral and filariae primordium. (e) Flattened female floral bud. (f) Female floral bud with initiation of styles and stigmata. (g) Transection of young inflorescence showing female and male flowers between filariae, all pieces are still covered by scales. (h) Young male and female flowers primordium, the gynoecium is still open in the last. Abbreviations: : female flowers; $\sigma^{7}$ : male flowers; ax: inflorescence axis; f: filariae; fp: female floral primordium; sc: scales; v: volva. Scales bar= (a) $0.5 \mathrm{~mm}$; (b,g,k) $200 \mu \mathrm{m}$; (c-f) $20 \mu \mathrm{m}$.

\subsection{Female Gametophyte Development}

In order to describe the development of the embryo sac and in the absence of an ovule, the term "lower" was used for the base of the NC proximal to the floral pedicel and the term "upper" was used for the distal region of the NC oriented to the styles (Figure 4a).

The NC in the interior of the ovary consists of parenchyma cells that are small and very compactly arranged, with dense cytoplasm. In this parenchymatous tissue, two megaspore mother cells (MMC) are differentiated and they are arranged longitudinally, with 2-4 cell layers separating them from the apex of the NC. The MMCs stand out due to their large size, which reaches $144 \times 64 \mu \mathrm{m}$, the cytoplasm is clear but very filamentous and a bulky nucleus reaches $49.2-52 \mu \mathrm{m}$ in diameter (Figure $4 \mathrm{a}, \mathrm{b}$ ). 


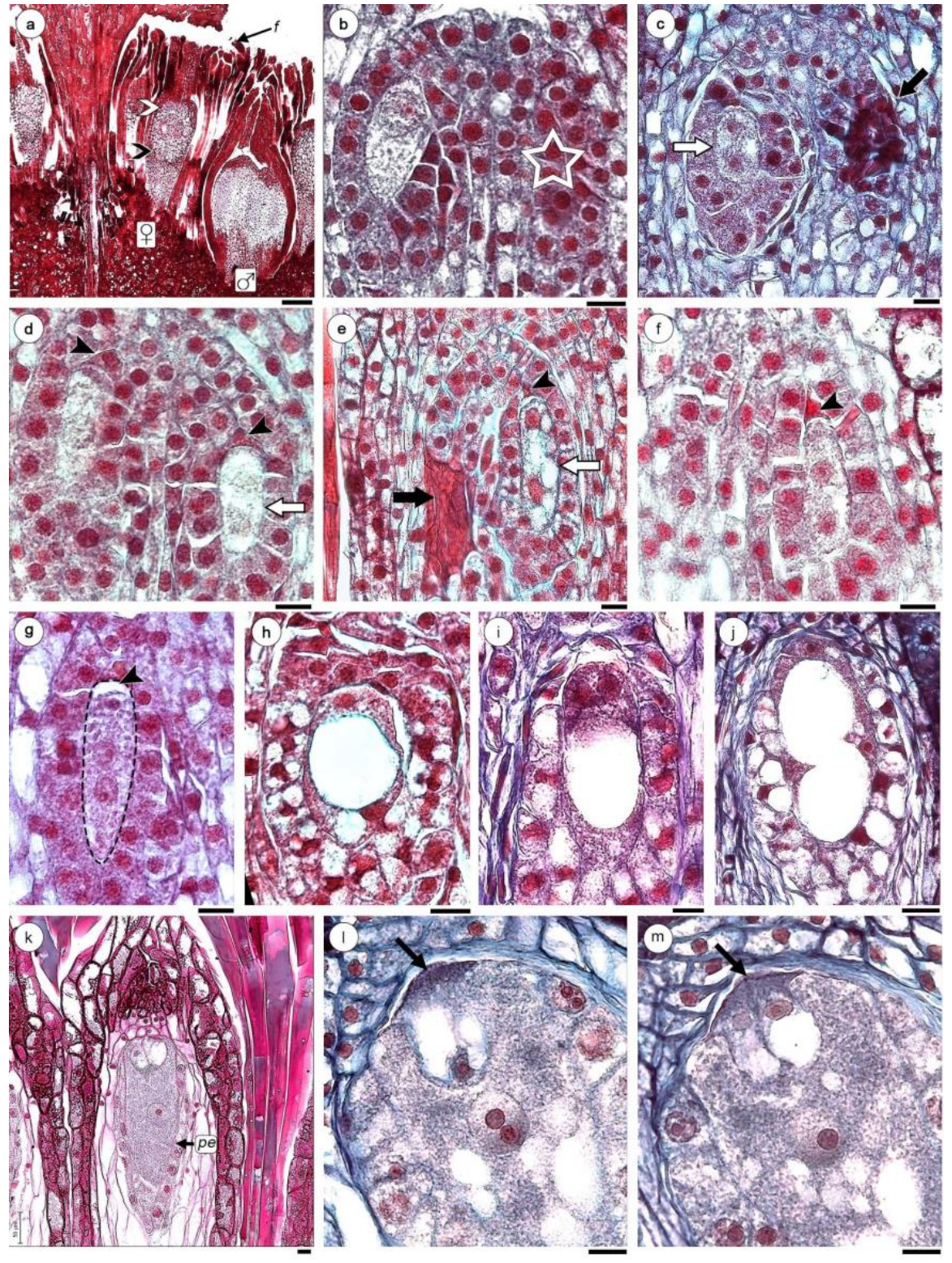

Figure 4. Female gametophyte development of H. cayennensis (LM). (a) Transection of inflorescence showing male (with microspore mother cells) and female flowers (with MMC), black arrow point indicates "lower" region of the nucellar complex (NC) and white arrow point shows "upper" or distal region of the NC. (b) Nucellar complex (NC) with one MMC, the second MMC is not visible in this section, its position is indicated with a star. (c) NC with dyad of megaspore (white arrow) and necrotic MMC (black arrow). (d) NC with pair of binucleate sporophytes, the apical cell is degenerating (black arrowhead) and basal is in second mitosis (white arrow). (e) NC with binucleate and vacuolated sporophytes (white arrow), aborted megaspore (black arrowhead) and necrotic MMC (black arrow). $(\mathbf{f}, \mathbf{g})$ trinucleate stages, black arrowhead indicates megaspore degenerated. $(\mathbf{h}-\mathbf{j})$ Gametophyte with 4 nuclei separated by a central vacuole (only two are visible in the sections $\mathbf{h}, \mathbf{i})$. (k) Mature gametophyte showing egg apparatus with two synergids, one egg cell and a central cell containing a single nucleus. $(\mathbf{l}, \mathbf{m})$ Serial sections of oosferic apparatus with filiform apparatus (arrows), (1) egg cell and central cell with large nucleus and two nucleoli. (m) Longitudinal sections of same embryo sac across synergids. Abbreviations: : female flowers; $\sigma^{x}$ : male flowers; f: filariae; pe: pseudo-endothelium. Scales bar $=(\mathbf{a})$ $0.2 \mathrm{~mm}$; (b-m) $200 \mu \mathrm{m}$.

In most ovary (up to 96\%) one MMC degenerate, leaving necrotic tissue in its place (Figure 4c,e, black arrows). The first meiotic division of the MMC develops a dyad (Figure 4c), the upper megaspore 
degenerates (Figure $4 \mathrm{~d}-\mathrm{g}$, arrowheads). The lower remains as functional megaspore (Figure $4 \mathrm{~d}$ ) and originates the binucleate gametophyte (Figure $4 \mathrm{~d}$,e, white arrows). A second mitotic cycle gives rise to a tetranucleate gametophyte (Figure $4 \mathrm{f}-\mathrm{j}$ ). With the progressive vacuolation, the four nuclei are pushed towards the periphery of the cell (Figure $4 \mathrm{~h}-\mathrm{j}$ ). The following events include both cell growth and increased cytoplasm density, as well as fragmentation of the vacuolar system (Figure 4k). Cytokinesis takes place resulting in an ES composed by four cells: the egg cell have one vacuole oriented towards the apex and two synergids with conspicuous filiform apparatus and vacuoles oriented towards the base of the ES (Figure $4 \mathrm{k}-\mathrm{m}$ ). The central cell have a single nucleus and numerous and small vacuoles (Figure $41, \mathrm{~m}$ ). The oosferic apparatus is located towards the upper portion of NC. The pseudo-endothelium remains surrounding the ES, with dense cytoplasmic cells (Figure 4k). Callose is absent both in MMC or during development of ES. In the cases where the two ES have been developed, they have the same ES as previously described.

\subsection{Embryo and Endosperm Formation}

When gynoecium development is completed and the ES are mature in female flowers, inside anthers of male flowers (of the same inflorescence) microsporogenesis is still in process, indicating the presence of protogyny. However, at the collection site, inflorescences were simultaneously observed in both states: some at female stage with exposed stigmata (stage II) and others at male stage with exposed and dehiscent anthers (state III). Despite the possibility of cross-pollination, the presence of pollen grains on stigmata or pollen tubes within styles or arriving to the embryo sac were not observed at any stage, neither in the analysis with light nor fluorescent microscopy.

Embryo and endosperm develop before pollen is mature and anthers dehisce in male flowers of the same inflorescence. Even though fertilization was never observed in this study, the egg cell constitutes the zygote and it is located at the upper apex and some small starch grains appear in the cytoplasm (Figure 5a-c). The zygote is quiescent, the nucleus of the central cell divides and the cell undergoes cytokinesis with the formation of an oblique wall in the basal third beginning the endosperm formation (Figure $5 b, c$ ). Endospermogenesis continues with successive mitosis followed by cytokinesis (Figure $5 \mathrm{~d}$ ). Due to its development, the pseudo-endothelial cells and nearby NC cells are crushed (Figure $5 b-d$ ).

Only when the endosperm is made of numerous cells, the zygote undergoes a first transverse division (Figure $5 \mathrm{e}-\mathrm{g}$ ). In this state, the male flowers of the same inflorescence are still immersed in the filariae layer; the separation of the tetrads and release of the microspores is observed inside their pollen sacs (Figure $5 \mathrm{~h}$ ).

In this species, the fruit is the unit of dissemination. The fruit is an achene, $0.5 \mathrm{~mm} \times 1.5 \mathrm{~mm}$ long, with a papillose apex. The wall of the fruit (Figure 5h,i) consists of 2-3 outer layers of cells with a completely tanniferous cytoplasm and abundant grains of starch. All fruits collected from completely dried infructescences have undifferentiated embryos, consisting of a few cells and multicellular endosperm. Remains of the pseudo-endothelium with dense cytoplasm surround the endosperm. All analysed achenes, which were already dispersed (and collected in the proximity of the mature and disintegrated infructescence), show an undifferentiated embryo consisting of few cells. No embryos with indications of germination or evidence of adhesion with roots of potential hosts were found. 

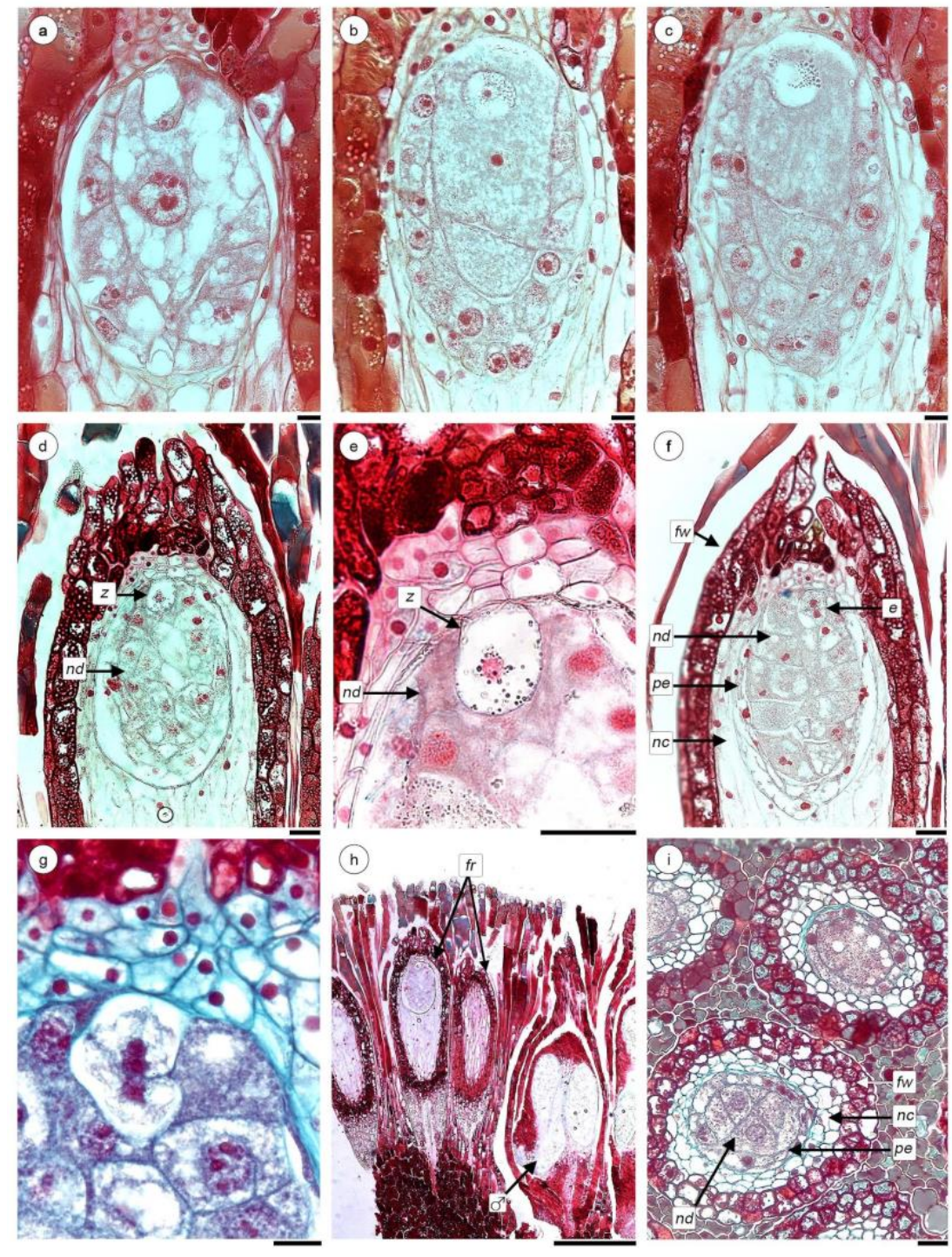

Figure 5. Embryo and endosperm of $H$. cayennensis development. (a) Vacuolized embryo sac. $(\mathbf{b}, \mathbf{c})$ Cytokinesis in central cell. (d) Longitudinal sections (LS) of fruit with endosperm and zygote. (e) Detail of zygote. (f) Bicellular embryo and multicellular endosperm. (g) Detail of bicellular embryo and surrounded endosperm cells. (h) LS of inflorescence with fruit and male flower still not anthetic. (i) Transection of fruits. Abbreviations: e: embryo; fr: fruits; fw: fruit wall; nc: nucellar complex; nd: endosperm; pe: pseudo-endothelium; $\sigma^{7}$ : male flower; $z$ : zygote. Scales bar $=(\mathbf{a}-\mathbf{c}, \mathbf{g}) 20 \mu \mathrm{m} ;(\mathbf{d}-\mathbf{f}, \mathbf{i})$ $50 \mu \mathrm{m} ;$ (h) $0.5 \mathrm{~mm}$.

\section{Discussion}

Balanophoraceae s.l. is definitely one of the most unusual eudicot families. Indeed, its genera are characterised by aberrant vegetative bodies $[4,13,27]$, highly reduced flowers $[2,12,28]$, inversion and aggressiveness of the ES [15], irregular embryogenesis and small and reduced embryos [2,16,28,29]. This study focused on H. cayennensis, a monoecious species with endogenously developed inflorescences. By analysing female flower development and embryology in detail, this study adds to the recent one on inflorescence structure and male flower development [12] and allowed disentangling of the reproductive phenology in this species and of flowering stages (in both male and female flowers) and fruit development. Furthermore, by putting results into a phylogenetic context (Table 1), this study highlights the lack of knowledge in floral development and embryology of holoparasitic Balanophoraceae s.l. taxa. 
Table 1. Summary of floral characteristics of Balanophoraceae s.l. (Bal. clade A o sensu stricto and clade B or Mystropetalaceae) and other related families according to the phylogeny proposed by Su et al. [5].

\begin{tabular}{|c|c|c|c|c|c|c|c|c|c|c|}
\hline Family & Genera & perianth $(\mathrm{FF})^{*}$ & styles & locules & ovule/others structures * & MMC/NC & MMC origin & ES type $/ \mathbf{n}^{\circ}$ nuclei & PSE & References \\
\hline Bal. s.str. & $\begin{array}{l}\text { Balanophora } \\
\text { J.R. Forst. \& G. Forst. }\end{array}$ & 0 & 1 & 0 & $\begin{array}{l}\text { massive central placental column that later } \\
\text { fuses with the ovary wall }\end{array}$ & 1 & 1, 4-sporic & $\mathrm{Pol} / \mathrm{B}$ & - & {$[6,28,30,31]$} \\
\hline Bal. s.str. & Langsdorffia Mart. & $\begin{array}{l}\text { tubular inconspicuous } \\
\text { segments perianth }\end{array}$ & 1 & 0 & $\begin{array}{l}\text { orthotropous, fused to the ovary, } \\
\text { placental-nucellar complex }{ }^{\mathrm{HS}}\end{array}$ & 1 & 1-sporic & - & - & {$[1,22,32,33]^{\mathrm{HS}}$} \\
\hline Bal. s.str. & $\begin{array}{l}\text { Thonningia } \\
\text { Vahl }\end{array}$ & $\begin{array}{l}0 \text { or tubular inconspicuous } \\
\text { segments perianth }\end{array}$ & 1 & 0 & orthotropous, fused to the ovary & - & - & - & - & [34] \\
\hline Bal. s.str. & Corynaea Hook. f. & 0 or 2 lip-like segment perianth & 2 & 1 & placental-nucellar-complex & 2 & 2-sporic & Allium/8 & - & {$[6,35]$} \\
\hline Bal. s.str. & $\begin{array}{l}\text { Ditepalanthus } \\
\text { Fagerl. }\end{array}$ & perianth ring adnate to ovary & 2 & 1 & free central placenta & - & - & - & yes & [36] \\
\hline Bal. s.str. & Helosis Rich. & 0 & 2 & $0 \mathrm{pg}$ & nucellar complex & 2 & 2-sporic & Helosis/4 & yes & this study \\
\hline Bal. s.str. & $\begin{array}{l}\text { Rhopalocnemis } \\
\text { Jungh. }\end{array}$ & 2 perianth crests adnate to ovary & 2 & 1 & $\begin{array}{c}\text { free central placenta, } \\
\text { placental-nucellar-complex }\end{array}$ & 2 & 1-sporic & - & yes & {$[37,38]$} \\
\hline Bal. s.str. & $\begin{array}{c}\text { Scybalium } \\
\text { Schott \& Endl. }\end{array}$ & 2 perianth lobes adnate to ovary & 2 & $2 \mathrm{pg}$ & $\begin{array}{l}\text { free central placenta, } \\
\text { placental-nucellar-complex }\end{array}$ & - & - & - & yes & {$[22,32]$} \\
\hline Bal. s.str. & Lathrophytum Eichler & 0 & 2 & 2 & central placenta & - & - & - & - & {$[5,22,32,33]$} \\
\hline Bal. s.str. & $\begin{array}{l}\text { Lophophytum } \\
\text { Schott \& Endl. }\end{array}$ & 0 & 2 & $2 \mathrm{pg}$ & placental-nucellar complex, ategmic ovule & 2 & $\begin{array}{l}1 \text {-sporic } \\
4 \text {-sporic }\end{array}$ & $\begin{array}{c}\text { Pol/8 } \\
\text { Adoxa/8 }\end{array}$ & no & {$[5,15,39]$} \\
\hline Bal. s.str. & $\begin{array}{l}\text { Ombrophytum } \\
\text { Poepp. ex Endl. }\end{array}$ & 0 & 2 & $2^{\mathrm{HS}}$ & ategmic ovule, placental-nucellar complex ${ }^{\mathrm{HS}}$ & - & - & - & - & {$[5,22,40] \mathrm{HS}$} \\
\hline Bal. s.str. & Chlamydophytum Mildbr. & 0 & 1 & 1 & - & - & - & - & & [41] \\
\hline Bal. s.str. & Sarcophyte Sparrm. & 0 & 1 & 3 & - & - & - & - & & [32] \\
\hline $\begin{array}{c}\text { Bal. B. } \\
\text { Mystropetalaceae } \\
\end{array}$ & $\begin{array}{l}\text { Dactylanthus } \\
\text { Hook. f. }\end{array}$ & 2(3) perianth members & 1 & $2 \mathrm{pg}$ & nucellar-complex & 2 & - & - & - & [7] \\
\hline $\begin{array}{c}\text { Bal. B. } \\
\text { Mystropetalaceae }\end{array}$ & $\begin{array}{l}\text { Hachettea } \\
\text { Baill. }\end{array}$ & 3-lobed cup on top of ovary & 1 & 1 & - & - & - & - & - & {$[4,27,32]$} \\
\hline $\begin{array}{c}\text { Bal. B. } \\
\text { Mystropetalaceae }\end{array}$ & $\begin{array}{l}\text { Mystropetalon } \\
\text { Harv. }\end{array}$ & 3-lobed cup on top of ovary & 1 & 1 & $\begin{array}{l}3 \text { ovules arising from a free placenta, each } \\
\text { being reduced to an embryo-sac }\end{array}$ & 1 & - & $\mathrm{Pol} / \mathrm{s}$ & - & {$[42-44]$} \\
\hline Schopfiaceae & $\begin{array}{l}\text { Quinchamalium Molina, } \\
\text { Arjona Cav., } \\
\text { Schoepfia Schreb. }\end{array}$ & 4-5-lobed, epigynous, connate & 3 & 1 & 3 unitegmic, ategmic ovules (only 1 develops) & 1 & 1-sporic & $\mathrm{Pol} / \mathrm{s}$ & - & [6] \\
\hline Misodendraceae & $\begin{array}{l}\text { Misodendrum } \\
\text { Banks ex DC. }\end{array}$ & 3-sepaline or vestigial & 1 & 1 & $\begin{array}{l}3 \text { ovules undifferentiated on a } \\
\text { free central placenta }\end{array}$ & 1 & & $\mathrm{Pol} / \mathrm{s}$ & - & {$[5,6,27,28,45]$} \\
\hline Loranthaceae & $\begin{array}{l}\text { Dendrophthoe Mart., } \\
\text { Nuytsia Tiegh., } \\
\text { Struthanthus Mart. }\end{array}$ & 6-7 petals & 1 & $0-4$ & ovary-ovule complex, mamelon & 1 & 1-sporic & $\mathrm{Pol} / \mathrm{s}$ & - & {$[6,28,46-48]$} \\
\hline
\end{tabular}

Abbreviations = Bal: Balanophoraceae. (FF) *: FF: female flowers, *: terminology used by authors in references. MMC: megaspore mother cell. MMC/NC: number of MMC by nucellar complex or ovules. ES: embryo sac. PSE: pseudo-endothelium presence. Double dashes indicate absence of data (i.e., data unknown). 0: absent, pg: post genital fusion of the placental tip or nucellar complex with the top of the ovary; Pol: Polygonum. ${ }^{\text {HS: }}$ H.A.S personal observations. 


\subsection{Female Flower Development}

Reduction is observed at all levels within female flowers of Helosis and related genera, starting from the perianth and styles to ovules (Table 1). Developmental studies proved critical to correctly assign organ identity, especially in the case of the perianth, where its identity has long been debated in Helosis. Taxonomic studies [1,20-22] characterised H. cayennensis female flowers as having two perianth forms: one is an entire ring of slightly elongated cells with papillose projections and the other perianth form is bifid, with two inconspicuous segments. Chodat and Bernard [23] described a concrescence between ovary and calyx. Howard [24] reported a bilabiate and triangular perianth in female flowers of H. cayennensis (incl. H. guianensis) and H. mexicana. Cardoso and Braga [9] also considered the entire ring of papillose projections in $H$. antillensis as perianth pieces and used the bifid versus entire perianth forms in their key to Helosis species. All these previous interpretations were, however, exclusively based on herbarium specimens with no evidence from developmental studies. For instance, our results show that the projections at the apex of the ovary are not perianth pieces, because they are formed at later stages of floral development, after the gynoecium is closed; therefore, they are rather of carpellar origin. Moreover, the two perianth forms actually correspond to different developmental stages: young flowers have two triangular projections between the styles (Figure 2c), whereas they form a ring and occupy the entire apex of the ovary in fully developed flowers (Figure 2i) and in fruits (Figure 5h). Therefore, based on our results, H. cayennensis and most likely also the other Helosis species do not develop any perianth.

Patterns in perianth presence or reduction appear to be consistent with recent phylogenetic relationships. In genera of Mystropetalaceae [5] a rudimentary perianth occurs in flowers of both sexes (Table 1). We thus agree with Su et al. [5], who state that "Reductions and losses of floral parts seen in Balanophoraceae s.str. (below) are not as pronounced in Mystropetalaceae. For example, a perianth is present on the female flowers of all three genera $[7,28,49]$ ". Mystropetalaceae is sister to the Misodendraceae/ Schoepfiaceae clade of hemiparasites [5], in which both families share the presence of flowers with perianth and three undifferentiated ovules (Table 1).

In contrast, the perianth is generally absent (the gynoecium is naked) or extremely reduced in female flowers of Balanophoraceae s.str. genera [5]. Interestingly, genus Corynaea, inferred as sister to Helosis ([S5]; formerly together into tribe Helosieae [1]), is taxonomically described as both with and without a perianth and if lacking it, then with two short and broad, lip-like segments instead that protrude above the ovary [1]. We suspect that developmental studies in this genus would reveal that these lip-like segments are in fact not perianth organs but of carpellar origin. Similarly, in female flowers of Langsdorffia, Rhopalocnemis [5] and Thonningia, taxonomic studies [37,38] report the presence of tubular perianths with small, inconspicuous segments fused to the ovary that could also represent a misinterpretation to be clarified with ontogenetic studies.

Gynoecium development in Balanophoraceae s.l. is also characterised by reductions. Notably, genera display a series of reductions at the ovule level, ranging from ategmic ovules to undifferentiated structures with a diffuse limit between the nucellus and placenta (see Sato [15] and Table 1). Such undifferentiated structures also occur in other Santalales such Schopfiaceae, Misodendraceae and Loranthaceae (Table 1). The lack of clear boundaries between the nucleus and the placenta makes anatomical interpretation of embryological structures difficult in the absence of developmental studies. This probably explains the historical debate in the interpretation of such structures and the subsequent proliferation of terms, in addition to the fact that most of the data in Table 1 are from taxonomic treatments.

To refer to the area with the diffuse limits, authors who studied the embryology in this family $[2,6,7,19,37,50-59]$ used a wide array of terms, like: mamelon, nucellar complex, placentalnucellar-complex, papilla, rudimentary ovary, free central placenta and naked (ategmic) orthotropous ovule. The latter three were also used in taxonomic descriptions of Helosis $[1,19,23]$. In our study, however, we preferred to use Holzapfel's [7] term 'nucellar complex' for the central structure in the ovary of $H$. cayennensis, where megaspore mother cells lie and embryo sacs develop. Indeed, Holzapfel [7] 
writes "An identification of the central complex as only either nucellus or placenta and consequently the suggestion that one or the other is completely absent, may indeed be of little merit at such a strong level of reduction, in particular since each term relates in parts to its position relative to the other" and continued "However, the term 'nucellar complex' has been chosen here to reflect the absolute necessity of the presence of a nucellus or nucellus remnant in the formation of megaspores."

In the hypothetical series of sequential fusion and reductions within the female flowers of Santalales [15], gynoecium ontogeny was studied in only three genera of Balanaphoraceae s.str.: Balanophora, Helosis and Lophophytum. Balanophora is the genus displaying the most reduced gynoecium, as it is a conical and massive body in which one embryo sac is formed [30,31] and a ovarian cavity does not develop [60]. Lophophytum is the opposite, as it is the only genus where the ovules are still distinguishable from the placenta; they are ategmic and only consist of a nucellus, without integuments [15]. During gynoecium development in Lophophytum two lateral projections develop in the central placenta, resulting into two nucellus primordia, by a post genital fusion the placental-ategmic ovules complex fused with the top of the ovary and thus forms two locules in the mature gynoecium [15]. Lophophytum represents the genus with less reduction of gynoecium between Balanaphoraceae s.l. In this hypothetical series of reductions, Helosis is intermediate, although among Balanaphoraceae s.l. it possesses the second-most reduced gynoecium. Our study shows that in $H$. cayennensis, after closure of the ovary walls and complete formation of a pair of styles derived from a pair of carpels, the remnant of the floral apex is resolved in a central hemispheric mass or NC with a pair of MMC (Figure 4d). Therefore, we showed that the NC is post genitally fused with the top of the ovary, filling the ovarian cavity. The existence of two MMCs and two styles and stigmata strongly suggests that the ovary of H. cayennensis is bicarpellate, a widespread condition in the Balanophoraceae s.1. [1,5,28]; (Table 1).

\subsection{Female Gametophyte Development}

Female gametophyte development is generally poorly studied in Balanophoraceae s.l. hampering comparison among genera. Furthermore, existing studies might report different results, as is the case of Helosis. In the first of the two studies on Helosis embryology (Chodat and Bernard [23], who studied $H$. guyanensis $=H$. cayennensis), the megaspore mother cell becomes the megaspore directly and produces two nuclei, one basal or "antipodal" (which soon degenerates) and the second "superior" nucleus that divides and produces an ES with four cells: two synergids, one egg cell and a central one. The present study shows that Chodat and Bernard [23] were partially correct and that the only discrepancy found is in the lower nucleus of the dyad that acts as functional megaspore. In the second study (Fagerlind [19], who studied H. cayennensis), two megaspore mother cells in the central papilla (synonym of NC) form a dyad by meiosis; the upper cell degenerates and the lower cell develops an 8-nucleate ES, bisporic and Allium-type. In contrast to Fagerlind [19], we never observed an 8-nucleate Allium-type embryo, despite having analysed hundreds of gynoecia. Our study indicates that Helosis follows a bisporic female gametophyte development, with no wall formation after meiosis II and one mitotic division results in four-celled ES provided with a typical egg apparatus and an enormous uni-nucleated central cell.

Four-celled, four-nucleated ES, with antipodals absent from the beginning, were described in plants with different pattern of ES formation (Figure 6): in monosporic Oenothera-type [47,61] and Nuphar/ Schisandra-type [characteristics of basal angiosperm taxa: Nymphaeales and Austrobaileyales [62-66]. The Nuphar/Schisandra-type of ES is similar to the Oenothera-type, differs only in the identity of the megaspore in the tetrad that develops into the ES: the chalazal megaspore is functional in the first, whereas the micropylar megaspore in the tetrad is functional in the second type of ES [67]. Similar four-nucleated ES develop from bisporic Podostemon-type and Polypleurum (=Dicraea)-type (Podostemaceae, [68,69] and in tetrasporic Plumbagella-type [47]. In bisporic Podostemonaceae and tetrasporic Plumbagella-type, the mature ES have diverse cellular configuration, with the four cells arranged in T-shape or in a row [47,70]. The mature embryo sac of Helosis is organised in the same way as the Nuphar/Schisandra-type and Oenothera-type; however, it originates from a bisporic development, which prompted us to assign it to its own type, the Helosis-type. From a comparative perspective, 
it is most similar to the Nuphar/Schisandra type since it derived from the "lower"(chalazal) nucleus (megaspore in the case of Helosis).

The gametophyte of Helosis is a variant (with a bisporic pattern of development) that exemplifies the concept of modular construction proposed for the evolution of the angiosperm female gametophyte [71]. According to this hypothesis, an ancestral four-celled/four-nucleate developmental module by duplication led to the seven cells/eight nucleated Polygonum-type ES, typical of most angiosperms $[64,67,71]$. Balanophoraceae s.str. are characterised by a wide variety of ES configurations (Table 1). An embryo sac that is 1-sporic Polygonum-type occurs in Balanophora [30,31]. Instead, in Lophophytum it is 4-sporic Adoxa-type [15] but previously described as 1-sporic Polygonum-type by Cocucci, [39] and in Corynaea it is 2-sporic Allium-type [35]. Because the origin and type of embryo sac are fully known only in these four Balanophoraceae s.str. genera [15]; (Table 1), it is not possible to further discuss these features in the context of the new phylogenetic relationships (but see Sato and Gonzalez [15]).

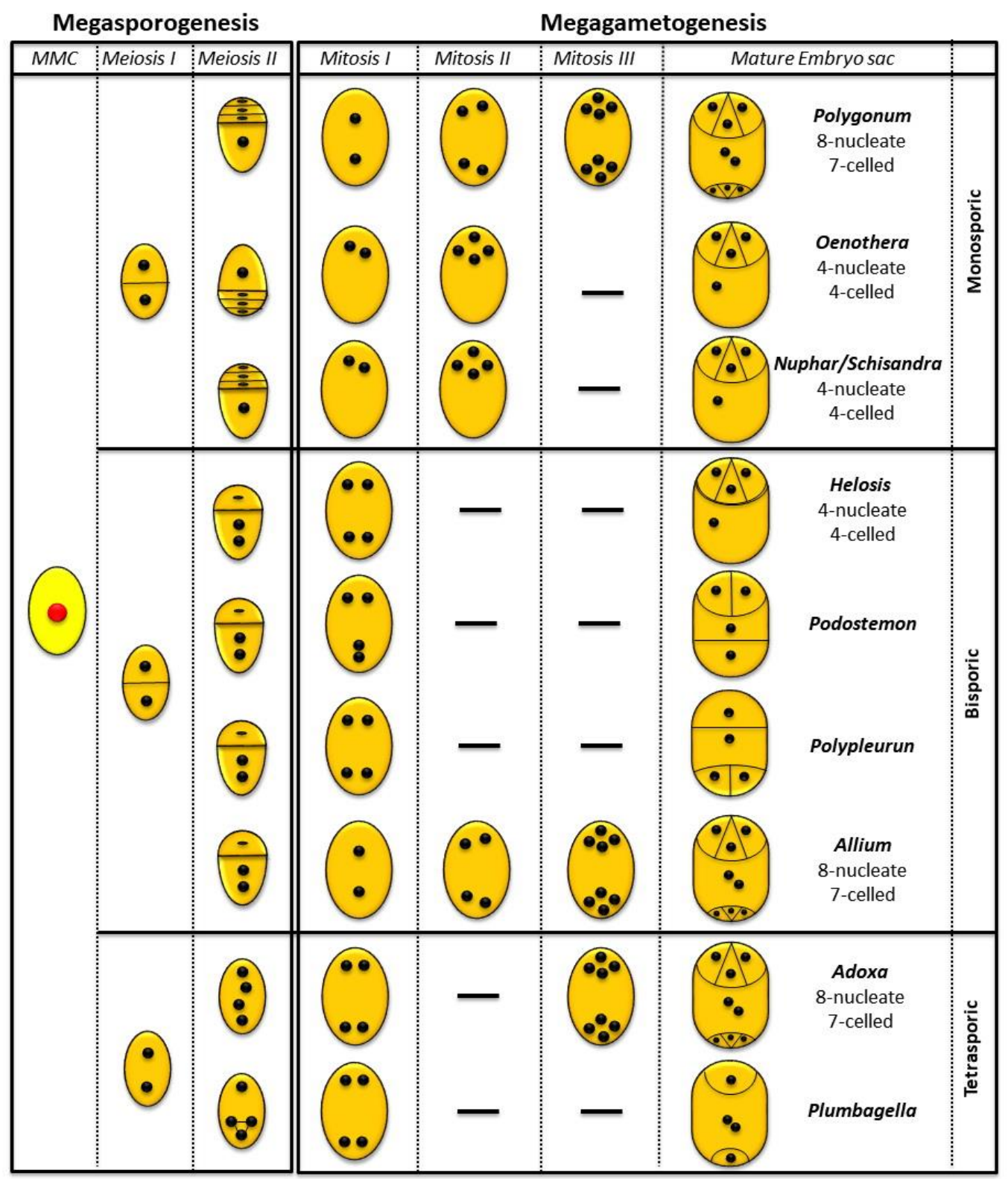

Figure 6. Comparative diagrams illustrating patterns of female gametophyte development between Helosis and others types of ES (based on Maheshwari [72], Tobe et al. [65] Johri et al. [6] and Sato \& Gonzalez [15]). 
Another characteristic that appears related to the ES of H. cayennensis is the presence of a layer of cells with dense cytoplasm that surrounds the ES. This layer is typically found in plants bearing thin unitegmic ovules, where the ES is frequently surrounded by a specialized layer of cells called endothelium or integumentary tapetum, derived from inner cells of the integument [73-76]. The cells are elongated with dense cytoplasm and become specialized to supply nutrients to the embryo sac. We found such cells of similar location and general morphology in a layer that encircled the MMC and later the ES of Helosis. Holzapfel [7] preferred to use "pseudo-endothelium" in flowers of Dactylanthus taylorii because they were derived from cells of the nucellar complex, these cells resemble an endothelium of unitegmic ovules. This pseudo-endothelium was observed in H. cayennensis also by Chodat and Bernard [23] and Fagerlind [19] and is also reported in some other members of the Balanophoraceae s.l. (Table 1. Scybalium: [32]; Rhopalocnemis: 2, [37]; Ditepalanthus: [19]).

\subsection{Endosperm, Embryo and Fruit Development}

Fertilization in Balanophoraceae s.l. is another poorly documented and apparently controversial feature. This is not surprising, given the highly reduced structures and the difficulties to identify and interpret them in these taxa. For instance, Umiker [52] and Chodat and Bernard [23] described that fertilization itself does not occur in Helosis, the embryo is very rudimentary, composed of a small mass of small cells immersed in the endosperm and devoid of a suspensor. According to Chodat and Bernard [23], the embryo in Helosis provides another example of "nouvel exampled' apogamie." In contrast, Fagerlind [19] described fertilization of ES in H. cayennensis and formation of few-celled embryo and a cellular endosperm. Here, we observed no pollen grains on stigmata, pollen tubes inside styles or near ES, neither in analysis with light or fluorescent microscopy. However, we clearly observe the formation of a cellular endosperm and a few-celled embryo, typical of the Balanophoraceae s.l. (Figure 5). This (apparent) absence of fertilization and successful embryo and endosperm formation, leads us to suggest that the embryo formation in Helosis occurs by parthenogenesis and that the endosperm development is autonomous.

Progeny segregation analysis, biochemical and molecular markers or estimation of DNA content or the "egg cell parthenogenetic capacity" tested through the auxin test would be necessary to definitely confirm our observation of parthenogenesis and autonomous endosperm development in H. cayennensis. However, during this study it was not possible to collect further plant material for such tests. Furthermore, it is not possible yet to cultivate this species and the tiny flower size does not allow bagging of female flowers or excising of anthers in male flowers. Nevertheless, a similar pattern in embryo and endosperm formation was also described in Balanophora [77,78] and Lophophytum [16,39], the only other two Balanophoraceae s.str. genera studied ontogenetically. In addition, apomixis was reported by Fagerlind [53] in a few species of Balanophora. Further embryological studies on more taxa, coupled with specific tests, are necessary to determine whether this is a shared feature in this newly circumscribed family.

Fruits were described as an achene with few layers of ovary cells contiguous to embryo in Helosis and in most genera of studied Balanophoraceae as well [1,15]. The concept of "seed" in the strict sense is, however, not applicable in the genera of Balanophoraceae s.l. [6,7], as there are no ovules, the ESs are embedded in parenchymatic mass devoid of teguments and in many cases it is not possible to even distinguish the nucella from the placenta. Therefore, the unit of dispersion is the achene with an undifferentiated embryo plus endosperm. Actually, Helosis and Balanophora would be included with in the so-called dust seed plants [79], because their unit of dispersion are among the smallest of all flowering plants. While Martin [80] separates such small-sized seeds into micro $(<0.2 \mathrm{~mm})$ and dwarf (0,2-2 mm), Baskin \& Baskin [81] simply considers them all as "undifferentiated," because of the presence of embryos with no cotyledon(s) and radicle. This undifferentiated embryo characterises also several other parasitic plants $[2,81,82]$. How seeds germinate is, however, known only in a few Balanophora species [31]. 


\section{Materials and Methods}

Helosis cayennensis (Sw.) Spreng. var. cayennensis was collected in the Apipé Grande Island of the Paraná river, Ituzaingó department, province of Corrientes, Argentina. This collection site is subject to periodic flooding and only two collections could be made: 2009 and 2014, the only couple of years in which the land was not flooded. In the two collections carried out, 83 inflorescences were obtained at different stages of development. According to morphology, the inflorescences were classified into four phenological states: I: flower bud formation, II: female phase: female flowers with exposed stigmata, III: male phase: male flowers with exposed and dehiscent anthers and IV: fruiting.

Material was fixed in FAA (formalin, 70\% alcohol and acetic acid, 90:5:5), dehydrated and then embedded in paraffin [83,84]. To carry out the embryological study, three portions of $1 \mathrm{~cm}^{2}$ of surface were taken in each inflorescence, at the base, middle and apical region. Each piece was subdivided to make transversal and longitudinal sections (plane in relation to flowers). Serial sections were cut 10 microns thick using a rotative microtome (Microm, Walldorf, Germany). Sections were stained with safranin - fast green [83-85]. Lugol was used for identification of starch and $\mathrm{FeSO}_{4}[83,85]$ and IKI- $\mathrm{H}_{2} \mathrm{SO}_{4}$ [85] for tannin recognition. Histological sections were analysed using a Leica DMLB2 light microscopy (LM), provided with a LEICA ICC50HD digital camera (Leica Microsystems GmbH, Germany). Polarized light was also used to locate lignified walls and identify the starch grains.

The sectioned and clarified gynoecium was stained with aniline-blue solution and observed by fluorescence microscopy (Leica DM 1000, Microsystems GmbH, Germany), in order to evaluate the pollen grains on stigmata and pollen tube growth $[86,87]$.

Since the flowers are smaller than $3 \mathrm{~mm}$ and emerge at different times from the layer of filariae in which they are embedded, density and floral sex ratio (number of male and female flowers) was calculated in 10 inflorescences (stages II and III); the number and sexuality of flower was recorder in 50 fields of $0.5 \mathrm{~mm}^{2}$ from each transection of inflorescence (parallel to the surface of the inflorescences). ImageJ software [88] was used for measuring floral and cellular parameters.

For scanning electron microscopy (SEM), the material fixed in FAA was dehydrated in an ascending series of acetone, dried to critical point in $\mathrm{CO}_{2}$ (Denton Vacuum LLC, DCP-1, Pleasanton, EUA) and sputter coated with gold-palladium (Denton Vacuum, Desk II, Pleasanton, EUA). SEM observations were performed at the Electron Microscopy Service of the Universidad Nacional del Nordeste (Corrientes, Argentina), using a Jeol LV 5800 microscope (JEOL Ltd., Tokyo, Japan), at $20 \mathrm{Kv}$.

Voucher specimens were deposited in the Herbarium of the Botanical Institute of the Northeast (CTES, Gonzalez and Popoff $\mathrm{N}^{\circ}$ 239; Gonzalez and Sato $\mathrm{N}^{\circ} 470$ ).

We compiled a list of selected relevant floral characteristics of Balanophoraceae s.l. and of other related families according to recent phylogenetic relationships by Su et al. ([5], Table 1).

\section{Conclusions}

Embryology of holoparasites is a poorly studied subject, perhaps due to the tiny size of their flowers, the complexity of their structure, the difficulty of their collection and the impossibility of cultivating these plants. The present work elucidates previously unclear or controversial aspects on the female embryology in Helosis and adds new findings. In particular, it shows that the Helosis female gametophyte is bisporic and develops from the lower megaspore cell. The mature embryo sac is composed of a typical egg apparatus and an enormous uni-nucleated central cell. The antipodals never form. The bisporic 4-nucleate/4-celled embryo sac is called Helosis-type, because is anatomic and structurally similar to the monosporic 4-nucleate/4-celled Oenothera-type embryo sac. No germinating pollen was observed in stigma or growth of pollen tubes in the styles, neither double fecundation, however a few cell embryo develops (typical of the family) and cellular endosperm. By comparing genera of Balanophoraceae s.l. among each other, this study not only supports the position of Helosis in the Balanophoraceae s.str. clade (Su [5]) and relationships among them but also clarifies embryological terminology, working towards creating a needed consensus. It also highlights a dramatic lack of knowledge in many aspects of floral development of this fascinating group. As most authors working 
on holoparasites mentioned, more embryological studies are needed on these species with such extreme reductions. Only with such information, will it possible to find support for current phylogenetic relationships, which suggest a paraphyletic Balanophoraceae s.l. and to increase our understanding of floral evolution of holoparasitic taxa in and beyond this family.

Author Contributions: Investigation, analyses, interpretation of data \& figures: A.M.G.; Material collection: A.M.G. \& H.A.S.; Writing: A.M.G. \& B.M.; Table 1: H.A.S.

Funding: This research was funded by the UNIVERSIDAD NACIONAL DEL NORDESTE (PICTO 199-2011 and PI- SGCyT 12P001, both to A.M.G.).

Acknowledgments: We thank Entidad Binational Yaciretá and Orlando Popoff for their collaboration in collecting the plant material. We thank the three anonymous reviewers for their suggestions.

Conflicts of Interest: The authors declare no conflict of interest.

\section{References}

1. Hansen, B. Balanophoraceae. Flora Neotrop. Monogr. 1980, 23, 1-80.

2. Kuijt, J. The Biology of Parasitic Flowering Plants; University of California Press: Berkeley, CA, USA, 1969.

3. Mauseth, J.D.; Hsiao, S.C.; Montenegro, G. Vegetative body of the parasitic angiosperm Helosis cayennensis (Balanoporaceae). Bull. Torrey Bot. Club 1992, 119, 407-417. [CrossRef]

4. Heide-Jørgensen, H.S. Parasitic Flowering Plants; Koninklijke Brill Academic Publishers: Leiden, The Netherlands, 2008.

5. $\mathrm{Su}, \mathrm{H} . ; \mathrm{Hu}, \mathrm{J}$; Anderson, F.E.; Der, J.P.; Nickrent, D.L. Phylogenetic relationships of Santalales with insights into the origins of holoparasitic Balanophoraceae. Taxon 2015, 64, 491-506. [CrossRef]

6. Johri, B.M.; Ambegaokar, K.B.; Srivastava, P.S. Comparative Embryology of Angiosperms; Springer: Berlin/Heidelberg, Germany, 1992.

7. Holzapfel, S. Studies of the New Zealand root-parasite Dactylanthus taylorii (Balanophoraceae). Englera 2001, 22, 3-176. [CrossRef]

8. Holzapfel, A.S.; Dodgson, J. Experimental Seeding Trials for the Root Parasite Dactylanthus taylorii; Doc Science Internal Series 173; Department of Conservation: Wellington, New Zealand, 2004; pp. 1-13.

9. Cardoso, L.J.T.; Braga, J.M.A. A new caribbean species of Helosis (Balanophoraceae) with a revised key to the genus. Syst. Bot. 2015, 40, 597-603. [CrossRef]

10. Eberwein, R.K.; Weber, A. Exorhopala ruficeps (Balanophoraceae): Morphology and transfer to Helosis. Bot. J. Linn. Soc. 2004, 146, 513-517. [CrossRef]

11. Eberwein, R.K. Morphologie und Taxonomie der Helosidoideae (Balanophoraceae). Linz. Biol. Beitr. 2000, 32, 615-616.

12. Gonzalez, A.M.; Popoff, O.F.; Salgado Laurenti, C. Structure of staminate flowers, microsporogenesis and microgametogenesis in Helosis cayennensis var. cayennensis (Balanophoraceae). An. Jard. Bot. Madr. 2013, 70 , 113-121. [CrossRef]

13. Gonzalez, A.M.; Mauseth, J.D. Morphogenesis is highly aberrant in the vegetative body of the holoparasite Lophophytum leandrii (Balanophoraceae): All typical vegetative organs are absent and many tissues are highly modified. Int. J. Plant Sci. 2010, 171, 499-508. [CrossRef]

14. Sato, H.A.; Gonzalez, A.M. Anatomía y desarrollo de la flor masculina, microsporogénesis y microgametogénesis en especies de Lophophytum (Balanophoraceae) en la Argentina. Bol. Soc. Argent. Bot. 2013, 48, 59-72.

15. Sato, H.A.; Gonzalez, A.M. Floral development and anatomy of pistillate flowers of Lophophytum (Balanophoraceae), with special reference to the embryo sac inversion. Flora 2016, 219, 35-47. [CrossRef]

16. Sato, H.A.; Gonzalez, A.M. Embryogenesis, endospermogenesis and fruit development in Lophophytum (Balanophoraceae): Focus on endosperm and embryo initiation. Flora 2017, 233, 79-89. [CrossRef]

17. Fontana, J.L.; Popoff, O.F. Helosis (Balanophoraceae) en Argentina. Bol. Soc. Argent. Bot. 2006, 41, 85-90.

18. Hsiao, S.C.; Mauseth, J.; Gomez, L. Growth and anatomy of the vegetative body of the parasitic angiosperm Helosis cayennensis (Balanophoraceae). Bull. Torrey Bot. Club 1993, 120, 295-309. [CrossRef]

19. Fagerlind, F. Bau und Entwicklung der floralen organe von Helosis cayennensis. Sven. Bot. Tidskr. 1938, 32, 139-159.

20. Martius, K.F.P. Balanophoraceae. Nova Genera Species Plant. Bras. 1829, 3, 181-188. 
21. Hooker, J.D.I. On the Structure and Affinities of Balanophoreae. Trans. Linn. Soc. Lond. 1856, 22, 1-68. [CrossRef]

22. Eichler, A.W. Balanophoreae. In Flora Brasiliensis; Martius, C.F.P., Eichler, A.W., Urban, I., Eds.; Wilhelm Engelmann: Leipzig, Germany, 1869; pp. 1-74.

23. Chodat, R.; Bernard, C. Sur le sac embryonnaire d' Helosis guyanensis. J. Bot. 1900, 14, 72-79.

24. Howard, R.A. The Balanophoraceae in the Caribbean Flora. Rhodora 1959, 61, 79-81.

25. Hansen, B.; Engell, K. Inflorescences in Balanophoroideae, Lophophytoideae and Scybalioideae (Balanophoraceae). Dan. Bot. Tidsskr. 1978, 72, 177-187.

26. Martinez y Pérez, J.L.; Acevedo Rosas, R. Balanophoraceae. In Flora de Veracruz. Fascículo 85; Instituto de Ecología: Mexico City, Mexico, 1995.

27. Nickrent, D.L. Parasitic Plant Connection. 1997. Available online: https://parasiticplants.siu.edu/ (accessed on 20 May 2018).

28. Kuijt, J.; Hansen, B. Flowering plants. Eudicots: Santalales, Balanophorales. In The Families and Genera of Vascular Plants XII; Kubitzki, K., Ed.; Springer: Berlin/Heidelberg, Germany; New York, NY, USA, 2015.

29. Treub, M. L'organe femelle et I'apogamie du Balanophora elongata. Ann. Jard. Bot. Buitenzorg 1898, 15, 1-25.

30. Hansen, B. The Genus Balanophora J. R. \& G. Foster. A Taxonomic Monograph. Dan. Bot. Ark. Udg. Dan. Bot. Foren. 1972, 28, 1-188.

31. Arekal, G.D.; Shivamurthy, G.R. Female gametophyte in two species of Balanophora-A reinvestigation. Phytomorphology 1978, 28, 7-13.

32. Harms, H. Balanophoraceae. In A. Die Natürlichen Planzenfamilien; Engler, E., Prantl, K., Eds.; Engelmann: Leipzig, Germany, 1935; pp. 296-339.

33. Fagerlind, F. Bau der floralen organe der gattung Langsdorffia. Sven. Bot. Tidskr. 1945, 39, 197-210.

34. Fawcet, W. XIV. On new Species of Balanophora and Thonningia, with a note on Brugmansia Lowi, Becc. Trans. Linn. Soc. Lond. 2nd Ser. Bot. 1886, 2, 233-247. [CrossRef]

35. Engell, K. Morphology and embryology of Scybalioideae (Balanophoraceae) 1. Corynaea crassa Hook. f. var. sprucei (Eichl.) B. Hansen. Bot. Tidskr. 1979, 73, 155-166.

36. Hansen, B. Flore de Madagascar et des Comores: Famille 61. Balanophoracees; Museum National d'Histoire Naturelle: Paris, France, 1984.

37. Lotsy, J.P. Rhopalocnemis phalloides Jungh. A morphological-systematical study. Ann. Jard. Bot. Buitenzorg 1901, 2, 73-101.

38. Shumei, H.; Murata, J. Balanophoraceae. Flora China 2003, 5, 272-276.

39. Cocucci, A.E. Lophophytum leandri megasporogenesis and gametogenesis. In Proceedings of the 5th International Symposium of Parasitic Weeds, Nairobi, Kenya, 24-30 June 1991; Ransom, J.K., Musselman, L.J., Worsham, A.D., Parker, C., Eds.; CIMMYT: Kenya, Nairobi, 1991; pp. 31-35.

40. Sleumer, H. Die Balanophoraceen argentiniens. Bot. Jahrb. 1954, 76, 271-280.

41. Halle, F. Illustration de deux rares Balanophoracées d'Afrique équatoriale appartenant auxgenres Chlamydophytum Mildbr. et Balanophora Forst. Adansonia 1978, 2, 249-261.

42. Harvey-Gibson, R.J. Observations on the morphology and anatomy of the genus Mystropetalon. Trans. Linn. Soc. Lond. 1913, 8, 143-154. [CrossRef]

43. Johnson, T. Mystropetalon Thomii, Harv. Ann. Bot. 1889, 4, 176. [CrossRef]

44. Engler, E. Die natürlichen Pflanzenfamilien; W. Engelmann: Leipzig, Germany, 1889; Volume 111, p. 252.

45. Zavaro, C.A.; Crisci, J.V.; Morrone, J.J. Synopsis and cladistics of the genus Misodendrum (Misodendraceae, Santalales). Fontqueria 1997, 48, 225-239.

46. Singh, B. A contribution to the floral morphology and embryology of Dendrophthoe falcata (L. f.) Ettingsh. Bot. J. Linn. Soc. 1952, 53, 449-473. [CrossRef]

47. Johri, B.M. Embryology of Angiosperms; Springer: Berlin, Germany, 1984.

48. Suaza-Gaviria, V.; Pabón-Mora, N.; González, F. Development and morphology of flowers in Loranthaceae. Int. J. Plant Sci. 2016, 177, 559-578. [CrossRef]

49. Hansen, B. The Balanophoraceae of continental Africa. Bot. Jahrb. Syst. 1986, 106, 359-377.

50. Hofmeister, W. Neuere beobachtungen über embryobildung der pahenogamen. Jahrb. Wiss. Bot. 1859, 1, 110.

51. Eichler, A.W. Balanophoraceae. In Prodromus, Systematis Naturalis Regni Vegetabilis; De Candolle, A.P., Ed.; Sumptibus Sociorum Treuttel et Würtz: Paris, France, 1873; pp. 134-136.

52. Umiker, O. Entwicklungsgeschichtlich-cytologische Untersuchungen an Helosis guyanensis Rich. Arb. Inst. Allg. Bot. Pflanzenphysiol. Univ. Zür. 1920, 23, 1-54. 
53. Fagerlind, F. Blüte und Blütenstand der Gattung Balanophora. Bot. Not. 1945, 45, 330-350.

54. Fagerlind, F. Beiträge zur Kenntnis der Gynöceummorphologie und Phylogenie der Santalales-Familien. Sven. Bot. Tidskr. 1948, 42, 195-229.

55. Fagerlind, F. Development and structure of the flower and gametophytes in the genus Exocarpus. Sven. Bot. Tidskr. 1959, 53, 257-282.

56. Davis, G.L. Systematic Embryology of the Angiosperms; Wiley: New York, NY, USA, 1966.

57. Teriokhin, E.S.; Yakovlev, M.S. Embryology of the Balanophoraceae. Bot. Zhurnal 1967, 52, 745-758.

58. Bhatnagar, S.P.; Johri, B.M. Embryology of Loranthaceae. In The biology of Mistletoes; Calder, M., Bernhardt, P., Eds.; Academic Press: London, UK, 1983; pp. 47-66.

59. Cocucci, A.E. New evidence from embryology in angiosperm classification. Nord. J. Bot. 1983, 3, 67-73. [CrossRef]

60. Zweifel, R. Cytologisch-embryologische untersuchungen an Balanophora abbreviata Blume und Balanophora indica Wall. Arb. Inst. Allg. Bot. Univ. Zür. II Ser. Nr. 1939, 84, 246-306.

61. Ishikawa, M. Studies on the Embryo Sac and Fertilization in Oenothera. Ann. Bot. 1918, 32, $279-317$.

62. Williams, J.H.; Friedman, W.E. The four-celled female gametophyte of Illicium (Illiciaceae; Austrobaileyales): Implications for understanding the origin and early evolution of monocots, eumagnoliids and eudicots. Am. J. Bot. 2004, 91, 332-357. [CrossRef] [PubMed]

63. Friedman, W.E. Sex among the flowers. Nat. Hist. 2006, 115, 48-53.

64. Friedman, W.E. Hydatellaceae are water lilies with gymnospermous tendencies. Nature 2008, 453, 94-97. [CrossRef] [PubMed]

65. Tobe, H.; Kimoto, Y.; Prakash, N. Development and structure of the female gametophyte in Austrobaileya scandens (Austrobaileyaceae). J. Plant. Res. 2007, 120, 431-436. [CrossRef]

66. Rudall, P.J.; Remizowa, M.V.; Beer, A.S.; Bradshaw, E.; Stevenson, D.W.; Macfarlane, T.D.; Tuckett, R.E. Comparative ovule and megagametophyte development in Hydatellaceae and water lilies reveal a mosaic of features among the earliest angiosperms. Ann. Bot. 2008, 101, 941-956. [CrossRef]

67. Friedman, W.E.; Ryerson, K.C. Reconstructing the ancient female gametophyte in Angiosperms: Insights from Amborella and other ancient lineages of flowering plants. Am. J. Bot. 2009, 96, 129-143. [CrossRef]

68. Battaglia, E. The Embryo Sac of Podostemaceae-An Interpretation. Caryologia 1971, 24, 403-420. [CrossRef]

69. Jäger-Zürn, I. Embryological and floral studies in Weddellina squamulosa Tul. (Podostemaceae, Tristichoideae). Aquat. Bot. 1997, 57, 151-182. [CrossRef]

70. Haig, D. New perspectives on the angiosperm female gametophyte. Bot. Rev. 1990, 56, 236-274. [CrossRef]

71. Friedman, W.E.; Williams, J.H. Modularity of the angiosperm female gametophyte and its bearing on the early evolution of endosperm in flowering plants. Evolution 2003, 57, 216-230. [CrossRef] [PubMed]

72. Maheshwari, P. An Introduction to Embryology of Angiosperms; McGraw-Hill: New York, NY, USA, 1950. [CrossRef]

73. Bouman, F. The ovule. In Embryology of Angiosperms; Johri, B.M., Ed.; Springer: Berlin, Germany, 1984; pp. 123-153. [CrossRef]

74. Bouman, F.; Boesewinkel, F.D. The seed: Structure and function. In Seed Development and Germination; Routledge: Abingdon-on-Thames, UK, 2017; pp. 1-24.

75. Kapil, R.; Tiwari, S.C. The integumentary tapetum. Bot. Rev. 2008, 44, 457-490. [CrossRef]

76. Endress, P.K. Angiosperm ovules: Diversity, development, evolution. Ann. Bot. 2011, 107, 1465-1489. [CrossRef]

77. Ernst, A.; Schmid, E. Über blute und frucht von Rafflesia. Ann. Jard. Bot. Buitenzorg 1913, 27, 1-58.

78. Chamberlain, C.J. The embryogeny of Balanophora. Bot. Gaz. 1914, 57, 542. [CrossRef]

79. Eriksson, O.; Kainulainen, K. The evolutionary ecology of dust seeds. Perspect. Plant Ecol. Evol. Syst. 2011, 13, 73-87. [CrossRef]

80. Martin, A.C. The comparative internal morphology of seeds. Am. Midl. Nat. 1946, 36, 513-660. [CrossRef]

81. Baskin, C.C.; Baskin, J.M. Seeds. Ecology, Biogeography, and, Evolution of Dormancy and Germination, 2nd ed.; Elsevier: Amsterdam, The Netherlands, 2014.

82. Baskin, C.C.; Baskin, J.M. Seeds: Ecology, Biogeography and Evolution of Dormancy and Germination; Academic Press: San Diego, CA, USA, 2001.

83. Johansen, D.A. Plant Microtechnique; McGraw-Hill: New York, NY, USA, 1940.

84. Gonzalez, A.M.; Cristóbal, C. Anatomía y ontogenia de semillas de Helicteres lhotzkyana (Sterculiaceae). Bonplandia 1997, 9, 287-294. 
85. Ruzin, S.E. Plant Microtechnique and Microscopy; Oxford University Press: Oxford, UK, 1999.

86. Martin, F.W. Staining and observing pollen tubes in the style by means of fluorescence. Stain Technol. 1959, 37, 125-128. [CrossRef]

87. Yi, W.; Law, E.; Mccoy, D.; Wetzstein, H.Y. Stigma development and receptivity in almond (Prunus dulcis). Ann. Bot. 2006, 97, 57-63. [CrossRef] [PubMed]

88. Rasband, W.S. ImageJ; National Institutes of Health: Bethesda, MD, USA, 1997-2019. Available online: http:/ /imagej.nih.gov/ij (accessed on 10 December 2018).

(C) 2019 by the authors. Licensee MDPI, Basel, Switzerland. This article is an open access article distributed under the terms and conditions of the Creative Commons Attribution (CC BY) license (http://creativecommons.org/licenses/by/4.0/). 